\title{
Barriers to Technology Integration in a Technology-Rich Environment
}

\author{
Kevin Schoepp \\ Zayed University, Abu Dhabi
}

\begin{abstract}
This paper reports on one segment of a research project which investigates what faculty members perceive to be acting as barriers in their attempts to integrate [information and communication] technology into their teaching at a laptop university. A web-based questionnaire was used to collect information from 69/288 (24\%) faculty members from a small U.A.E. university. From the data gathered, patterns and associations emerged from which the researcher is able provide recommendations as to what type of interventions and programs could be provided to increase current levels of teaching with technology.
\end{abstract}

\section{Introduction}

This current research project is based upon the belief that only recently, since the spread of the World Wide Web and high speed computer processors, has computer-based technology - henceforth referred to in this paper as 'technology' - become easy enough to use and of enough value for most faculty to pursue it as a tool for teaching. Such technology had previously only been the realm of the innovators and early adopters (Rogers, 1995). However, technology is now accessible to far more faculty and students. In addition, with more and more institutions removing the barrier of access through the implementation of programs such as a laptop program, the degree to which technology is being integrated into teaching and learning must be further explored. Hence, this paper attempts to answer the question: What do faculty in a technology-rich environment perceive as barriers to technology integration? In answering this question, the researcher will be able to provide 
recommendations such as the creation of a technology integration plan which includes a structured professional development program in the hopes of overcoming these barriers.

The first section of this paper, after defining barriers to technology integration, will outline three key barrier concepts. This will be followed by a discussion of the methods that were employed to obtain the results. The third section will describe in detail the quantitative findings of this study. These findings will then be examined in the discussion. To conclude, the recommendations section will provide ideas for overcoming barriers to technology integration.

\section{Barriers to Technology Integration}

A barrier is defined as "any condition that makes it difficult to make progress or to achieve an objective" (WordNet, 1997). The objective under scrutiny in this study is increased technology integration. The understood and yet unspoken connotation of a barrier is that its removal acts as an aid towards the achievement of the objective. Therefore, the study of barriers as they pertain to technology integration is essential because this knowledge could provide guidance for ways to enhance technology integration. Ertmer (1999) echoed this sentiment, in stating that by providing "teachers with knowledge of barriers, as well as effective strategies to overcome them, it is expected that they will be prepared to both initiate and sustain effective technology integration practices" (Conclusion section, ף 4).

\section{Common Barriers}

The act of integrating technology into teaching and learning is a complex process and one that may encounter a number of difficulties. These difficulties are known as barriers. In order to lay the foundation for this entire section, it is necessary to illustrate the established set of common technology integration barriers. Although these are often labeled, measured, and rated differently, researchers (Hadley \& Sheingold, 1993; Anderson et al.1998; Jacobsen, 1998; Ertmer, 1999; Ertmer et al., 1999; Newhouse, 1999; Beggs, 2000; Becker, 2000b; Rogers, 2000; Cuban, 2001; Pajo \& Wallace, 2001; Beaudin, 2002; 
Snoeyink \& Ertmer, 2002; Bariso, 2003) have identified these or similar variations as widespread barriers: lack of computers, lack of quality software, lack of time, technical problems, teacher attitudes towards computers, poor funding, lack of teacher confidence, resistance to change, poor administrative support, lack of computer skill, poor fit with the curriculum, lack of incentives, scheduling difficulties, poor training opportunities, and lack of vision as to how to integrate.

In order to draw conclusions, researchers have long attempted to categorize or group barriers through a factor analysis. This is the approach taken in this study. Hadley and Sheingold (1993) conducted a study involving known technology integrators at the 4-12 grade level, their factor analysis identified the following seven themes (ranked here from the most to least) which accounted for over $50 \%$ of the variance. The most cited barriers to technology integration were- 1. Poor administrative support 2. Problems with time, access, space, supervision, and operations 3. Poor software 4. Curriculum integration difficulties 5. Teacher's attitudes and knowledge towards computers 6. Computer limitations and inadequate numbers of computers 7 . Lack of technical support.

Building upon the barrier work done by Hadley and Sheingold (1993), Jacobsen (1998) identified similar findings at the post-secondary level. The major difference was that the majority of faculty felt that technology was now an adequate fit with their curriculum. This finding was by no means an isolated incident. In fact, it seems to represent the beginning of a trend. In another study conducted at a post-secondary institution, Beggs (2000) also found that a lack of relevance to the faculty member's discipline received the second lowest barrier rank with nearly $65 \%$ of all respondents rating it only somewhat important or not important. Other parallels between these works was that lack of time, lack of equipment and lack of training were the top rated barriers to technology integration. Beaudin (2002) continued to investigate the role of barriers into technology integration using the instrument designed by Jacobsen but this time in the $\mathrm{K}-12$ environment. Though major technological advances had been made between Beaudin's study and the seminal work done by Hadley and Sheingold, 
the results were strikingly similar. External barrier items such as time and poor accessibility remained highly consequential. A similarity between the Jacobsen, Beggs, and Beaudin findings - in striking contrast to the Hadley and Sheingold work - was that teachers were least likely to agree with the concept that computers do not fit with the course or the curriculum. Obviously, a shift in one component has occurred, since fewer instructors now perceive a misalignment between their course content and technology integration. A logical conclusion from this is that this belief in combination with a technology-rich environment should only aid faculty in better integrating technology with course content.

\section{Barriers Always Present}

To best demonstrate the existence of barriers to technology integration independent of the environment, it is essential to examine the recent history of technology in the classroom. This allows one to see that as the main barrier - lack of technology access - was removed, other barriers still remained. Nevertheless, common sense dictates that in institutions that lack sufficient access to technology, effective technology integration would be a daunting, if not impossible task. It appears that Maddux's (1998) claim that "it is essential that computers be placed in classrooms. Until that happens, true integration is unlikely to take place" (p. 8) remains true.

According to Ertmer (1999) teachers would not automatically integrate technology into teaching and learning even if barriers such as access, time, and technical support were removed. Furthermore, Cuban, Kirkpatrick, and Peck (2001), in reviewing the frequency of teacher technology use in technology abundant high schools, stated that decision makers believe that creating abundant access to technology would lead to an increased level of technology use in the classroom. However, while this is certainly a requirement, it is but an initial step. They found that abundant access to technology was not enough to ensure technology integration. This means that even in better than average technology-rich schools, teachers were still not integrating technology to any substantial degree. It appeared that even the straightforward task of scheduling a computer lab acted as a barrier. Yet again, the 
essential element of this study is that as a laptop institution, access to technology is not an issue. This provides depth to the investigation into the remaining technology integration barriers.

The relationship between plentiful technology, enhanced technology integration, and barriers does not appear to be straightforward. In a longitudinal study built around a portable computer program, Newhouse (1999) stated that many of the common barriers associated with the adoption of the innovation were still present. Some of the barriers preventing teachers from integrating technology were poor computer literacy, lack of time, lack of confidence, and hardware malfunctions. Though access as a barrier had been overcome, others still remained. Similar sentiments are echoed by Cuban (2001) since he found that lack of time and inadequate generic training remained technology integration barriers in technology-rich high schools. He also noted that at technology-rich Stanford University, faculty continue to cite lack of time and poor technical support as barriers to technology integration.

\section{Barrier Elimination}

Recommendations as to the methods of eliminating technology integration barriers differ according to the type and intensity of the barrier. However, regardless of the barriers involved, "if teachers do not have sufficient equipment, time, training, or support, meaningful integration will be difficult, if not impossible, to achieve" (Ertmer, 1999, Obtaining Resources Section, \1).

To summarize the generally agreed upon concepts, Rogers (2000) wrote:

1. the less sophisticated technology integrator will require more professional development (sessions on ways to integrate technology) and more basic technical support (who to call when the computer crashes) because they are less independent; 
2. the more advanced technology integrator will require more sophisticated technology support (things like learning how to make a CD) and advanced professional development (sharing sessions with other advanced integrators).

Ertmer (1999) explains that less advanced levels of professional development could mean that teachers will

need opportunities to observe models of integrated technology use, to reflect on and discuss their evolving ideas with mentors and peers, and to collaborate with others on meaningful projects as they try out their new ideas about teaching and learning with technology. (Developing a Vision section, T 2)

Prior to even these recommendations, Fabry and Higgs (1997) posited that one method to enable teachers to experience the potential of technology is to have them use the technology as productivity, management, and communication tools. This initial introduction is believed to be an integral stage in the progression toward technology integration.

\section{Method}

\section{Survey}

A four-part, anonymous, web-based questionnaire was used to collect information from faculty members from a small U.A.E. University spread over two separate campuses. Multiple invitations to participate were distributed by the researcher via University email. Complete data was collected from 69 faculty members out of the possible 288 ( $24 \%$ return). Of these, 68 completed the web-based version while one participant provided a paper version because of technical problems encountered during data submission.

The focus of this paper is on the findings from the Barriers section alone. This section was comprised of 20 items. The items employed a Likert scale (1- Strongly Disagree- not a barrier, 2- Agree, 3- Undecided, 4- Agree, 5- Strongly Agree- a major barrier) to indicate the degree to which faculty perceived an item to be a barrier. Cronbach's alpha showed a 
reliability of .80 for this scale. This indicates a strong level of internal consistency. Past research (Hadley \& Sheingold, 1993; Jacobsen, 1998) guided the creation of the list of barriers. It was felt that an adapted list was required because the commonly reported barrier of poor access to technology was not a concern in this technology-rich environment.

\section{Participants}

No general demographic data such as gender, age, or years teaching was collected because these variables were not considered useful for providing technology integration recommendations. However, some background into the participants is needed. The participants are all expatriates with at least 3 years' teaching experience (a condition of employment) coming from a variety of primarily Anglophone countries. In relation to technological proficiency, there was expected to be a range of skill levels, but a basic skill level was expected to exist because "the university puts a lot of emphasis on information technology" (Kontos, 2001, ๆ 23). At the University this emphasis is demonstrated through the laptop ownership program, the mandatory use of an electronic grade and attendance application, and the pervasive use of communication technology such as email.

\section{Setting}

The cornerstone of this technology-rich environment is the laptop computer that is provided to each faculty member and student. Besides the laptops, a number of other resources make this institution technology-rich. Regarding data storage and sharing, there are a number of external computer drives that allow faculty to share files with one another or with students. Many departments use these network drives to share important program information, but a number of departments use the course management software, Blackboard $^{\mathrm{TM}}$, for this purpose.

Every classroom in the institution is fully wired for high speed Internet access, and includes a digital projector and printer. Besides the standard Office ${ }^{\mathrm{TM}}$ software installed on each computer, other more targeted software packages are available for download off the 
network. Other types of technology such as digital cameras, audio devices, and a recording studio are also available and in use. The English department, for instance, has recorded all their own listening activities through utilization of the recording studio. The recordings are then delivered to the students as .mp3 digital audio files using the laptops.

\section{Results}

Although there is a wide range to the degree in which faculty members integrate technology, all faculty experience barriers to technology integration. Table 1 shows the items in a descending manner for level of agreement according to the item's mean score. The dichotomous score for each variable has also been included. The dichotomous score was calculated by assigning 1 point for either a Strongly Agree or an Agree and no value for the other options. Hence, the maximum score that could be achieved on this scale was 69 . This scale is useful in identifying the number of times a barrier was actually identified as being a barrier.

Table 1. Rank of Barriers to Integrating Technology

\begin{tabular}{|l|l|l|l|l|}
\hline Item & Mean & $\begin{array}{l}\text { Std. } \\
\text { Dev. }\end{array}$ & Dich. & Dich. \% \\
\hline $\begin{array}{l}\text { Faculty unsure as to how to } \\
\text { effectively integrate technology. }\end{array}$ & 4.04 & .812 & 58 & $84.1 \%$ \\
\hline $\begin{array}{l}\text { The current reward structure does } \\
\text { not adequately recognize those } \\
\text { utilizing technology. }\end{array}$ & 3.88 & .993 & 45 & $65.2 \%$ ** \\
\hline $\begin{array}{l}\text { There are no program standards as } \\
\text { to what is expected for teaching with } \\
\text { technology. }\end{array}$ & 3.84 & .993 & 47 & $68.1 \%$ * \\
\hline $\begin{array}{l}\text { There is a lack of sufficient } \\
\text { technology training. }\end{array}$ & 3.67 & 1.159 & 47 & $68.1 \%$ * \\
\hline
\end{tabular}




\begin{tabular}{|c|c|c|c|c|}
\hline $\begin{array}{l}\text { There is a lack of technical support } \\
\text { regarding the technology. }\end{array}$ & 3.61 & 1.191 & 44 & $63.8 \%$ \\
\hline $\begin{array}{l}\text { Faculty do not have sufficient time to } \\
\text { integrate technology. }\end{array}$ & 3.61 & 1.297 & 42 & $60.1 \%$ \\
\hline $\begin{array}{l}\text { There is a lack of support from } \\
\text { administration. }\end{array}$ & 3.52 & 1.119 & 39 & $56.5 \%$ \\
\hline $\begin{array}{l}\text { There is inadequate financial support } \\
\text { to develop technology-based } \\
\text { activities. }\end{array}$ & 3.39 & 1.166 & 33 & $47.8 \%$ ** \\
\hline Faculty lack basic technology skills. & 3.36 & 1.029 & 36 & 52.2 * \\
\hline $\begin{array}{l}\text { Technology training is offered at } \\
\text { inconvenient times. }\end{array}$ & 3.35 & 1.122 & 33 & 47.8 \\
\hline $\begin{array}{l}\text { Generic technology training is } \\
\text { irrelevant to teacher needs. }\end{array}$ & 3.26 & 1.171 & 31 & 44.9 \\
\hline $\begin{array}{l}\text { The curriculum does not allow } \\
\text { enough time to integrate technology. }\end{array}$ & 3.09 & 1.257 & 30 & 43.5 \\
\hline $\begin{array}{l}\text { Faculty is not interested in } \\
\text { integrating technology. }\end{array}$ & 2.90 & 1.002 & 24 & 34.8 \\
\hline $\begin{array}{l}\text { There is not enough evidence that } \\
\text { using technology will enhance } \\
\text { learning. }\end{array}$ & 2.81 & 1.047 & 18 & $26.1^{* *}$ \\
\hline Technology is unreliable. & 2.81 & .974 & 19 & $27.5^{*}$ \\
\hline $\begin{array}{l}\text { Classroom management is more } \\
\text { difficult when using technology. }\end{array}$ & 2.54 & 1.119 & 18 & 26.1 \\
\hline $\begin{array}{l}\text { Software is not adaptable for } \\
\text { meeting student needs. }\end{array}$ & 2.41 & .828 & 7 & $10.1^{* *}$ \\
\hline Technology does not fit well for the & 2.30 & 1.142 & 13 & 18.8 * \\
\hline
\end{tabular}




\begin{tabular}{|l|l|l|l|l|}
\hline course I teach. & & & & \\
\hline $\begin{array}{l}\text { There is a scarcity of technology for } \\
\text { faculty. }\end{array}$ & 1.97 & .891 & 6 & 8.7 \\
\hline $\begin{array}{l}\text { There is a scarcity of technology for } \\
\text { the students. }\end{array}$ & 1.88 & .883 & 5 & 7.2 \\
\hline
\end{tabular}

* The dichotomous rank is higher than the mean rank

** The dichotomous rank is lower than the mean rank

The current study found that the most highly identified barriers were faculty's knowledge as to how to effectively integrate technology and the shortcomings of the current reward structure. As would be expected in a laptop environment, the least identified statements were "there is a scarcity of technology for faculty" and "there is a scarcity of technology for the students." The three other most highly rated barriers were lack of program standards, lack of technology training, and lack of technical support.

Interestingly enough, the barriers rated at the extremes, either as a major or inconsequential barrier, also recorded the smallest standard deviation. Only $7 / 20$ barriers had a standard deviation of less than one. Of these, none were ranked from major to inconsequential barrier in positions 4 through 14 . This means that the opposite ends of the scale had the least amount of variance and indicates a higher level of agreement for these items. The most neutrally ranked barriers also exhibited the highest standard deviations; hence, these results indicate that additional analysis is required.

As would be expected, the dichotomous scores showed general agreement with the mean rank. The Spearman correlation coefficient, designed to analyze ranked variables, measured .885 which indicates a very strong correlation. Only eight items were recognized as barriers by more than half of the respondents. These items in descending order from most strongly identified as a barrier to the weakest of the agreed upon barriers are:

\section{Faculty are unsure as to how to effectively integrate technology}


2. The current reward structure does not adequately recognize those utilizing technology

3. There are no program standards as to what is expected for teaching with technology

4. There is a lack of sufficient technology training

5. There is a lack of technical support regarding the technology

6. Faculty do not have sufficient time to integrate technology

7. There is a lack of support from administration

8. Faculty lack basic technology skills.

It appears that most faculty believe that the software and hardware is adequate. The weakness of the program is lack of training, support, time, and professional development that would help foster technology integration.

In addition to the aforementioned mean and dichotomous data, an exploratory factor analysis of the barrier items was conducted. The factor analysis was done in order to learn how the barriers may be related to one another. For the purposes of the study, only the strongest positive relationships (above .40) have been shown. (see Table 2).

Table 2. Barrier Factor Analysis

\begin{tabular}{|c|c|c|}
\hline $\begin{array}{l}\text { Component } 1 \\
\text { Eigenvalue- } 4.62\end{array}$ & $\begin{array}{l}\text { Factor } \\
\text { Loadings }\end{array}$ & $\begin{array}{l}\text { Variance } \\
\text { Percentage }\end{array}$ \\
\hline $\begin{array}{l}\text { There is a lack of technical support regarding the } \\
\text { technology. }\end{array}$ & .826 & \multirow{3}{*}{13.62} \\
\hline Technology training is offered at inconvenient times. & .801 & \\
\hline There is a lack of sufficient technology training. & .712 & \\
\hline \multicolumn{3}{|l|}{$\begin{array}{l}\text { Component } 2 \\
\text { Eigenvalue- } 3.55\end{array}$} \\
\hline There is a lack of support from administration. & .665 & 13.01 \\
\hline
\end{tabular}




\begin{tabular}{|c|c|c|}
\hline $\begin{array}{l}\text { The current reward structure does not adequately } \\
\text { recognize those utilizing technology. }\end{array}$ & .804 & \\
\hline Faculty is not interested in integrating technology. & .448 & \\
\hline Faculty lack basic technology skills. & .488 & \\
\hline $\begin{array}{l}\text { Faculty unsure as to how to effectively integrate } \\
\text { technology. }\end{array}$ & .617 & \\
\hline $\begin{array}{l}\text { There are no program standards as to what is } \\
\text { expected for teaching with technology. }\end{array}$ & .582 & \\
\hline $\begin{array}{l}\text { Component } 3 \\
\text { Eigenvalue- } 1.84\end{array}$ & & \\
\hline Technology is unreliable. & .505 & \multirow{3}{*}{12.77} \\
\hline There is a scarcity of technology for faculty. & .901 & \\
\hline There is a scarcity of technology for the students. & .907 & \\
\hline \multicolumn{3}{|l|}{$\begin{array}{l}\text { Component } 4 \\
\text { Eigenvalue- } 1.6\end{array}$} \\
\hline $\begin{array}{l}\text { Faculty do not have sufficient time to integrate } \\
\text { technology. }\end{array}$ & .779 & \multirow{3}{*}{12.31} \\
\hline $\begin{array}{l}\text { The curriculum does not allow enough time to } \\
\text { integrate technology. }\end{array}$ & .714 & \\
\hline $\begin{array}{l}\text { There is inadequate financial support to develop } \\
\text { technology-based activities. }\end{array}$ & .711 & \\
\hline $\begin{array}{l}\text { Component } 5 \\
\text { Eigenvalue- } 1.21\end{array}$ & & \\
\hline $\begin{array}{l}\text { There is not enough evidence that using technology } \\
\text { will enhance learning. }\end{array}$ & .767 & 11.13 \\
\hline
\end{tabular}




\begin{tabular}{|l|l|l|}
\hline Technology does not fit well for the course I teach. & .671 & \\
\hline Software is not adaptable for meeting student needs. & .583 & \\
\hline $\begin{array}{l}\text { Classroom management is more difficult when using } \\
\text { technology. }\end{array}$ & .500 & \\
\hline $\begin{array}{l}\text { Component } 6 \\
\text { Eigenvalue- 1.05 }\end{array}$ & & 6.44 \\
\hline $\begin{array}{l}\text { Generic technology training is irrelevant to teacher } \\
\text { needs. }\end{array}$ & .925 & 69.28 \\
\hline Total Variance Explained & & \\
\hline
\end{tabular}

The factor analysis (using varimax rotation) revealed six separate components (related variables) which account for nearly $70 \%$ of all the variation. A further analysis of the components was done which involved identifying the mean of each of the relationships from the Likert scale measure. This same analysis was done using the total dichotomous score. Table 3 shows the complete agreement between the ranks. Both measures confirm that the barriers within Component 3 were perceived to be of little consequence, while the barriers within Components 1 and 2 were major obstacles to technology integration.

Table 3. Component Rank Comparison

\begin{tabular}{|l|l|c|l|l|}
\hline Rank & Likert Mean & Component & Dich. Mean & Rank \\
\hline 2 & 3.54 & 1 & 41.3 & 2 \\
\hline 1 & 3.59 & 2 & 41.5 & 1 \\
\hline 6 & 2.22 & 3 & 10 & 6 \\
\hline 3 & 3.36 & 4 & 35 & 3 \\
\hline 5 & 2.52 & 5 & 21.25 & 5 \\
\hline 4 & 3.26 & 6 & 31 & 4 \\
\hline
\end{tabular}


The components provide additional insight into the relationships between the barriers. The following section indicates these components according to the composition of the individual barriers if a relationship is evident.

The common theme amongst the items which encompass Component 1 is that of a lack of technology training and support. The three barriers in this group accounted for nearly $14 \%$ of the total variance. In addition, the items were very tightly loaded with the lowest item registering .71 . This component was also the second highest rated as a barrier.

Another easily identifiable relationship exists between the barriers that are Component 3. The significance of this component is that it has been established as of the least consequence because it ranks at the bottom of both the scales. The three items were extremely strongly correlated. Two of the items were above .90 while the third item registered above .50 . The theme for these items seems to be related to the technologyrichness of the University. Two items pertain directly to the adequate amounts of technology at the University and the third is a refutation that technology is unreliable. Participants strongly believe that the University is a technology-rich environment.

Although Component 2 is a larger component than any other which emerged, it also had a dominant theme. It included 6 barriers which ranged in factor loadings from .80 to .49 and still accounted for over $13 \%$ of the total variance. It was also rated as the most dominant barrier. The theme around which these barriers are grouped is the lack of general technology support. Whereas Component 1 was specific to training, this component was far more general. It included such items as lack of reward structure, lack of program standards, and faculty unsure as to how to integrate technology.

The fourth component accounted for $12.31 \%$ of the total variance and had three items with a range of .71 to .79 . The component was the third most strongly identified regarding barriers. It had a rather neutral group mean for the Likert scale of 3.36. The most obvious theme is that of the lack of time. Two items are time items and the third item claimed there is inadequate financial support. All of these items are obvious external barriers that 
have had a more dominant role in previous research. Both Beaudin (2002) and Jacobsen (1998) found that lack of time was perceived to be the strongest barrier to the integration of technology.

Component 5 lists four barriers which seem to be grouped according to the general lack of belief as to the efficacy of technology use in the classroom. However, these items were only the second lowest ranked barriers. These items accounted for $11.13 \%$ of the variance, and had factor loadings from .50 to .77 . Items such as There is not enough evidence that using technology will enhance learning and technology does not fit well for the course I teach typify the comments from technology non-users.

The final component is comprised solely of the barrier which claims Generic technology training is irrelevant to teacher needs. This component is a bit of an anomaly because it would seem to be very closely related to Component 1 which is themed around lack of training and support. However, the factor analysis did not indicate a strong relationship. It was the fourth rated barrier component and had both the mean Likert score, 3.26, and the dichotomous barrier score, 31 , which were closest to the centre.

\section{Discussion}

As was anticipated, findings of the perceptions of barriers to technology integration both confirmed and contradicted prior work. It is perhaps within this construct that the influence of the technology-rich environment is most intense. This intensity is most evident when evaluating the overall rank of barriers. The following section will demonstrate the ways in which the current findings both affirm and refute prior research.

In the current study, scarcity of technology for either faculty or students was the least cited barrier. The barrier most referred to was the belief that faculty are unsure as to how to integrate technology. These findings were supported by both the mean scores and the dichotomous scores. It clearly appears that the technology-rich environment influences the perception of barriers, especially those that pertain to the accessibility of technology. This is 
understandable because availability of technology has been removed as a barrier. These findings were further supported through the factor analysis and subsequent component ranks. There was a strong consensus between the faculty members as to which barriers were of consequence and which were of little consequence. This is a powerful finding because this information can be used to design and create appropriate interventions. It is easier to target interventions if a consensus exists.

At times, the findings of this study differ from both the Jacobsen (1998) and Beaudin (2002) research possibly because of the technology-rich nature of the University. At other times, there was accord. Both of those studies found that a lack of time to integrate technology and the difficulty in scheduling enough computer time for classes were the two dominant barriers. As was stated, these were not the most cited barriers in the current research. Concurrence between this study and the Jacobsen and Beaudin projects emerges when looking at the general theme of support. This includes such concepts as technological support, administrative support, and adragogical support. Faculty or teachers in all of the studies did not feel as they were being provided with enough support to become effective technology integrators. Context specific support for this claim can be straightforwardly displayed. One of the core components for any university interested in integrating technology would be to have people whose job it is to train faculty in the use of the university's software. For the past year, no such person existed on either campus. Faculty had no one to turn to for basic software support or professional development. Any training that was being offered was done in a haphazard manner and relied upon volunteers from faculty and staff. It is very evident as to why faculty would feel that there is a lack of support. To summarize the findings of this section, the faculty feel that there is more than enough technology available to them. However, they do not believe that they are being supported, guided or rewarded in their attempt to integrate technology into their teaching. 


\section{Recommendations}

One of the goals of this research was to be able to provide informed recommendations with regard to the development of a technology integration plan and the design of appropriate professional development. Information garnered from the results of the barrier evaluations makes this possible.

\section{Technology Integration Plans}

Research studies indicate that the implementation levels of technology into teaching and learning remain low (Cuban, 2001; Cuban et al. 2001; Ertmer, 1999; Olsen, 2001). The purpose of much of the technology-based barrier research in education is to provide the foundation from which a technology integration plan can be started or evaluated. This is of the utmost importance because an ever increasing research pool (Anderson et al., 1998; Boe, 1989; Boyd, 1997; Caverly, Peterson, \& Mandeville, 1997; Cuban et al.; Scheffler \& Logan, 1999; Vaughan, 2002) is demonstrating that providing access to technology is not enough; faculty or teachers require guidance and need to be trained in methods to integrate technology into their teaching. This section will investigate essential components of a technology integration plan since it will form the basis for any intervention because "the purpose of technology planning... is to provide a foundation on which an effective curriculum of technology use in education can be built and maintained" (Blount, et al., 2002, p. 2).

Hence, the first major recommendation is to develop a technology integration plan for the University. Researchers (Anderson et al., 1998; Fabry \& Higgs, 1997; Rogers, 2000) recommend the creation of such a plan because it as an integral component of any attempt to increase the levels of technology integration. The findings from this research project indicate that faculty have a strong desire for curriculum integration, technology standards, and more effective professional development. Since these are the critical components of a technology integration plan, a technology plan which has facets of these should be created. 


\section{Curriculum Integration}

An essential component of any technology integration plan is to integrate technology into the curriculum. From this research project, the findings from the barriers to technology integration and concerns about technology integration sections indicate that faculty perceive the lack of formal technology curriculum integration as a barrier to their implementation, and that it is much easier to maintain ignorance towards an innovation without this guidance. Hence, integrating technology into the current curricula is paramount if real and sustainable integration is to occur. With the key barrier of lack of access removed, the University is ready to add technology to the curricula.

To facilitate this integration, the University will need to provide adequate support. This means that the required technical training will need to be offered to faculty. Hence, the University should restore, on a permanent basis, the position of IT trainer. In addition, the University will need to seek the guidance from their existing faculty members who are advanced technology integrators and from their educational technologists and instructional designer to help create the curricula which integrates technology. These same people along with the Center for Teaching and Learning will need to be charged with developing a structured professional development program aimed at teaching with technology, not teaching technology. Finally, the University should reward faculty in their attempts to integrate technology in their teaching by, for example, prioritizing the allotment of professional development funds to faculty members interested in pursuing technology related professional development opportunities or by providing release time as an incentive.

\section{Technology Standards}

Within this study, the lack of technology standards also proved to be a barrier to technology integration and limit implementation because faculty do not know what is expected from them. This needs to be addressed, so developing a set of technology standards is the third recommendation. 
Faculty need to know what is expected of them with regard to technology standards. Technology competencies for teachers are revealed in the Educational Technology Standards and Performance Indicators for All Teachers, which are a set of six standards and 23 corresponding performance indicators (International Society for Technology in Education, 2000). These have been designed to guide teacher education programs and to provide guidelines for practicing teachers. They are broad enough to be open for jurisdictional interpretation, but they do establish a clear understanding of what teachers should be able to do with regard to technology. In the current environment, these standards can be used as a starting point from which to build context specific standards. Both curriculum integration and technology standards are essential components of a technology integration plan, but neither of these concepts are attainable without adequate professional development.

\section{Professional Development}

"Another important component of the technology plan is professional development and support for teachers. No plan, no matter how well conceived, will be of any value if it is not implemented at the building and classroom levels" (November, Staudt, Costello, \& Huske, 1998, I 12). The results of the current study demonstrate the importance of designing targeted professional development. Fortunately, there is also significant research which offers suggestions as to how to design effective technology training. Therefore, the design of targeted, structured, and permanent professional development is the final recommendation from this study. This could be accomplished with the support of the Centre for Teaching and Learning. This is a department with a mandate to aid the development of teaching at the University.

According to Vaughn (2002) "the key to successful intervention is to personalize the innovation by taking the concerns of those engaged in the change process and accepting those concerns as crucial components and legitimate reflections of the change process" ( $(\mathbb{1}$ Implications for Educational Practice). Any professional development program needs to be multi-faceted in order to meet the needs of the very diverse population (Bybee, 2001). For 
example, a faculty member who claims that there is not yet enough evidence regarding the efficacy of integrating technology into teaching will require a very different intervention than a faculty member who is convinced of the value of technology integration but is struggling to find the time to use technology in their lessons. Skeptical faculty may need to witness an effective lesson by another faculty member who uses technology. This could be followed by a team taught lesson between the two. Convinced yet struggling faculty may need to work on a team with a number of other like-minded colleagues to generate ideas or create activities together. Both of these groups could benefit from release time to work learn to better integrate technology into their teaching. By taking into account the concerns of faculty, one is better able to design appropriate interventions and avoid a focus on generic technology training that is often "irrelevant to teachers' specific needs" (Cuban et al., p.826).

This means that rather than generic technology training, methods such as peer discussions, sharing sessions, peer coaching, and team teaching should be utilized (Boyd, 1997; Caverly et al., 1997; Garet, Porter, Desimone, Birman, \& Yoon, 2001). Moreover, since fragmentation often plagues learning opportunities for teachers, courses, workshops, and institutes must be coordinated or sustained over time so that teachers get both depth and breadth in what they need to know and be able to do (Bybee \& Loucks-Horsley, 2000). Long-term professional development programs, not just events, are required for technology integration to succeed.

\section{Discussion/Reflection Questions}

\section{Discuss}

this paper

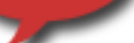

1. The most highly rated barrier was Faculty are unsure as to how to effectively integrate technology. What steps do you feel should be taken in a technology-rich environment to overcome this barrier?

2. As a faculty member, what type of guidance from your administration do require to become an effective technology integrator?

3. Is integrating technology into your teaching worth the effort? 


\section{About the Author}

Kevin Schoepp is the Educational Technology Specialist within the Readiness Program at Zayed University. He has taught English in Thailand, Costa Rica, Turkey, and Canada. His main area of interest is the impact that teaching with technology can have on student learning.

\section{References}

Anderson, T., Varnhagen, S., \& Campbell, K. (1998). Faculty adoption of teaching and learning technologies: Contrasting earlier adopters and mainstream faculty. The Canadian Journal of Higher Education, 2(3), 71-98.

Bariso, E. U. (2003). The computer revolution: Friend or foe to FE college staff. British Journal of Educational Technology, 34(1), 85-88.

Beaudin, L. C. (2002). Bernard Lonergan's notions of authenticity and technology integration. Unpublished doctoral dissertation, University of Calgary, Calgary, Alberta, Canada.

Becker, H. J. (2000). Internet use by teachers. In Technology and learning (pp. 80-111). San Francisco: Jossey-Bass.

Beggs, T. A. (2000). Influences and barriers to the adoption of instructional technology. In Proceedings of the Mid-South Instructional Technology Conference. (ERIC Document Reproduction Service No. ED446764)

Blount, J., Blunt, S., Bock, R., Bowen, M., Britt, M., Chandler, A., et al. (2002). Guidebook for developing an effective instructional technology plan: Version 3.5. Retrieved July 9, 2003, from <http://www.nctp.com/downloads>

Boe, T. (1989). The next step for educators and the technology industry: Investing in teachers. Educational Technology, 29(3), 39-44.

Boyd, E. (1997). Training-on-demand: A model for technology staff development. Educational Technology, 37(4), 46-49. 
Bybee, R. W. (2001). Effective professional development for technology teachers. The Technology Teacher, 61(3), 26-29. Retrieved May 17, 2003, from WilsonWeb database.

Bybee, R. W., \& Loucks-Horsley, S. (2000). Advancing technology education: The role of professional development. The Technology Teacher, 60(2), 31-34. Retrieved May 17, 2003, from WilsonWeb database.

Caverly, D., Peterson, C., \& Mandeville, T. (1997). A generational model for professional development: Training teachers to use computers. Educational Leadership, 55(3), 56-59. Retrieved September 3, 2002, from Expanded Academic ASAP database.\$

Cuban, L. (2001). Oversold and underused: Computers in the classroom. London: Harvard University Press.

Cuban, L., Kirkpatrick, H., \& Peck, C. (2001). High access and low use of technologies in high school classrooms: Explaining an apparent paradox. American Educational Research Journal, 38(4), 813-834.

Ertmer, P. A. (1999). Addressing first- and second-order barriers to change: Strategies for technology integration. Educational Technology Research and Development, 47(4), p. $47-61 . Z$

Ertmer, P. A., Addison, P., Lane, M., Ross, E., \& Woods, D. (1999). Examining teachers beliefs about the role of technology in the elementary classroom. Journal of Research on Computing in Education, 32(1), 54-71. Retrieved May 17, 2003, from Academic Search Premier database.

Fabry, D. L., \& Higgs, J. R. (1997). Barriers to the effective use of technology in education: Current status. Journal of Educational Computing Research, 17(4), 385-395.

Garet, M. S., Porter, A. C., Desimone, L., Birman, B. F., \& Yoon, K. S. (2001). What makes professional development effective? Results from a national sample of teachers. American Educational Research Journal 38(4), 915-945. 
Hadley, M., \& Sheingold, K. (1993). Commonalities and distinctive patterns in teachers' integration of computers. American Journal of Education, 261-315.

International Society for Technology in Education. (2000). Educational technology standards and performance indicators for all teachers. Retrieved July 9, 2003, from <http://cnets.iste.org/teachers/t_stands.html>

Jacobsen, D. M. (1998). Characteristics and adoption patterns of faculty who integrate technology into teaching and learning in higher education. Unpublished doctoral dissertation, University of Calgary, Calgary, Alberta, Canada. Retrieved January 6, 2004, from <http://www.ucalgary.ca/ dmjacobs/phd/diss/>

Kontos, G. (2001). The laptop university: A faculty perspective, Educational Technology Review 9(1), Oct 24 <http://www.aace.org/pubs/etr/issue1/kontos.cfm>.

Maddux, C. D. (1998). Barriers to the successful use of information technology in education. Computers in the Schools, 14(3/4), 5-11.

Newhouse, P. (1999). Examining how teachers adjust to the availability of portable computers. Australian Journal of Educational Technology, 15(2), 148-166. <http://www.ascilite.org.au/ajet/ajet15/newhouse.html>

November, A., Staudt, C., Costello, M., \& Huske, L. (1998). Critical issue: Developing a school or district technology plan. Retrieved July 8, 2003, from <http://www.ncrel.org/sdrs/areas/issues/methods/technlgy/te300.htm>

Olsen, F. (2001). Duke U. decides against requiring freshmen to own laptops. The Chronicle of Higher Education: Information Technology. Retrieved April 12, 2004, from <http://chronicle.com/free/2001/12/2001121101t.htm>

Pajo, K., \& Wallace, C. (2001). Barriers to the uptake of web-based technology by university teachers. Journal of Distance Education, 16(1). Retrieved June 22, 2003, from <http://cade.athabascau.ca/vol16.1/pajoetal.html> 
Rogers, E. M. (1995). Diffusion of innovations (4 ${ }^{\text {th }}$ ed.). New York: Free Press.

Rogers, P. L. (2000). Barriers to adopting emerging technologies in education. Journal of Educational Computing Research, 22(4), 455-472.

Scheffler, F. L., \& Logan, J. P. (1999). Computer technology in schools: What teachers should know and be able to do. Journal of Research on Computing in Education 31(3), 305-326.

Snoeyink, R., \& Ertmer, P. A. (2002). Thrust into technology: how veteran teachers respond. Journal of Educational Technology Systems, 30(1), 85-111.

Vaughan, W. (2002). Professional development and the adoption and implementation of new innovations: Do teacher concerns matter? International Electronic Journal For Leadership in Learning, 6(5), Retrieved October 22, from <http://www.ucalgary.ca/ iejll/volume6/vaughan.html>

WordNet 1.6 Princeton University (1997). Retrieved June 24, 2003, from <http://dictionary.reference.com/search?q=barrier> 